

\section{DISCLAIMER}

This report was prepared as an account of work sponsored by an agency of the United States Government. Neither the United States Government nor any agency Thereof, nor any of their employees, makes any warranty, express or implied, or assumes any legal liability or responsibility for the accuracy, completeness, or usefulness of any information, apparatus, product, or process disclosed, or represents that its use would not infringe privately owned rights. Reference herein to any specific commercial product, process, or service by trade name, trademark, manufacturer, or otherwise does not necessarily constitute or imply its endorsement, recommendation, or favoring by the United States Government or any agency thereof. The views and opinions of authors expressed herein do not necessarily state or reflect those of the United States Government or any agency thereof. 


\section{DISCLAIMER}

Portions of this document may be illegible in electronic image products. Images are produced from the best available original document. 


\section{NOTICE}

This report was prepared to document work sponsored by the United States. Government. Neither the United States nor its agent, the Department of Energy, nor any Federal employees, nor any of their contractors, subcontractors, or their employees, makes any warranty, express or implied, or assumes any legal liability or responsibility for the accuracy, completeness, or usefulness of any information, apparatus, product or process disclosed, or represents that its use would not infringe privately owned rights.

\section{ABSTRACT}

This study evaluates the local geothermal permitting practices of the four Geysers-Calis toga KGRA counties (i.e. Lake, Mendocino, Napa and Sonoma), in California, and the ways in which these processes could be expedited. The detailed analys is of local permitting processes undertaken in the course of this project revealed great variation in procedural approach, types of conditions imposed, phrasing of conditions and length of time it takes to process use permits; and these variations are described in the report. The analysis also revealed a number of interesting techniques employed by one or the other of the counties, or by Imperial County, to improve the process. These techniques are also described. Finally, four alternative approaches to expediting the local geothermal permitting process are identified. 
TABLE OF CONTENTS

Introduction

A. Status of Each County's General Plan and/or General Plan Program

1. Sonoma County

2. Lake County

3. Napa County

4. Mendocino County

B. The General Plan's Indirect Relationship to Geothermal Development

C. General Attitude Toward Geothermal Development and Potential Conflicts

D. Geothermal Elements

1. State Law

2. Counties' Positions Regarding Preparation of Geothermal Elements

3. Imperial County's Geothermal Element

4. Analysis

E. Specific Plans

1. State Law

2. Franz Valley Specific Plan

3. Analysis

F. Overlay Zoning

Summary and Conclusions

Attachment A - Geothermal Element (Guidelines) A-1

Attachment B - Imperial County Geothermal Goals - 1975 B-1

Attachment C - Geothermal Goals, Objectives and Policies Contained in the Imperial County General Plan 
Under California State Law (Government Code, Section 65302). each county in the State is required to prepare a county-wide General Plan. As defined by the law, a General Plan is a policy document consisting of nine mandatory elements: land use, circulation, open space, conservation, housing, noise, safety, seismic safety and scenic highways. Additional elements such as parks and recreation and geothermal are permitted, however. Within the context of the subjects addressed in a county's General Plan, the Plan becomes the principal policy. document guiding the future development of the county.

The following two sections of this report describe the status of the General Plans or General Plan preparation programs for each of the four Geysers KGRA counties*, and discuss potential conflicts between adopted General Plan policies and geothermal development. The next section assesses each county's attitude toward geothermal development as expressed in their adopted General Plan or in some other adopted policy statements, and the next section discusses the subject of geothermal elements of county General Plans. These two sections are followed by discussions about specific plans and overlay zoning, and finally a set of conclusions are drawn that cover this portion of the Policy Development Program.

* It should be noted that the research done in preparation of this report was conducted during the spring of 1980, therefore the status of local general plans is reported as of that time. Report production and review processes have occupied the intervening time between the spring of 1980 and the summer of 1981. Currently the Lake County Draft General Plan is being printed for distribution prior to the Planning Commission public hearing scheduled for July, 1981. The Mendocino County Draft General Plan is being held by the Planning Commission while the Circulation Element is being revised in compliance with a court order. It is expected the Plan will be adopted later in the summer, and submitted to the Superior Court for acceptance in the fall. 
A. STATUS OF EACH COUNTY'S GENERAL PLAN AND/OR GENERAL PLAN PROGRAM

Since State law requires that every county in the State have a General Plan, the four counties (Sonoma, Lake, Napa and Mendocino) each have complied. However, the approach that each county has taken in the preparation of their Plan has been unique. Moreover, two of the counties -- Lake and Mendocino -- are currently in the process of comprehensively revising their Plans. Because each county's Plan is somewhat different than the others and because each county is in a slightly different position with regard to the planning process, the following evaluation of General Plans affecting the Geysers-Calistoga KGRA is expressed on a county-by-county basis.

\section{Sonoma County}

The Sonoma County General Plan was adopted by the Board of Supervisors in January, 1978. Within the Conservation Element of the Plan, there is a section dealing with geothermal resources. This section provides a very brief discussion of what the geothermal resource consists of and the history of its development in the county. This section then goes on to identify eight issues of importance to geothermal development. The issues identified include:

"1. Long-term geothermal-resource utilization,

2. The multiple use of the geothermal-resource area,

3. Environmental impacts of geothermal-resource extraction, 
4. The reclamation of the geothermal-resource area,

5. A geothermal-resource management program,

6. Data gathering and monitoring within the geothermal-resource area,

7. Multi-jurisdictional responsibilities and regulating powers, and

8. Conflicts with other land uses in natural areas." (pp. 72-73)

Within the section of the Plan dealing with goals and policies, the Plan states, "It shall be the goal of Sonoma County to provide for a planned production within geothermalresource areas. A program of planned geothermal production should focus on maximum long-term utilization of the resource and on the mitigation of adverse environmental impacts." (p. 17) The policies that follow this overriding goal are:

"a. Consider action by the Board of Supervisors to initiate a comprehensive geothermal resourcemanagement program.

b. Apply high standards governing all phases of geothermal exploration and production, including restoration of all such areas to acceptable conditions once the resource becomes nonproductive.

c. Encourage compatible, comprehensive multiple-use programs for geothermal leaseholds. 
d. Insure that undesirable effects of by-products and waste in the geothermal areas are minimized.

e. Support monitoring of the geothermal resource by appropriate Sonoma County departments and other relevant agencies." (p.17)

In the section of the Conservation Element dealing with geothermal resources, a series of recommendations are made for specific action. These recommendations are:

\footnotetext{
"a. A comprehensive geothermal-resource management program should be formulated and utilized.

b. Geothermal exploration in production areas should be established.

c. Restoration of the natural environment within geotherma1-production areas should be promoted. An interjurisdictional program should be established to monitor the environmental effects of geothermal-resource production and county, state, and federal regulations should be enforced.

d. A format to gather data and monitor the resource should be devised in order to fully support the comprehensive resource-management program." (p. 73)
}

The Land Use Map that accompanies the Plan classifies most of the area within the KGRA as Undeveloped Forest, Grasslands; however, Knights Valley is indicated as Orchards and Vineyards, while the western end of the valley is designated for General Agriculture. A second map accompanying the Plan titled "Resource and Undeveloped Areas" further refines the land use designations within the KGRA. On this map, most of the area within the KGRA is indicated as Managed Resource Areas. This designation incorporates 
agriculture, timber, and geothermal resource lands. There are also several areas, primarily within the Big Sulphur Creek Drainage and along the Sonoma County-Lake County Line just south of this, that are classified as Natural Areas. Two areas are designated as Parks. One, at the upper end of the Big Sulphur Creek Drainage, is indicated as Pine Mountain Recreation Area, and is a federal recreation area. A second is located along the County Line on: the slopes of Mount St. Helena, and is indicated as Robert Louis Stevenson State Park.

\section{Lake County}

The Lake County General Plan, which was adopted in September, 1967, and which has been amended from time to time, has been determined to be inadequate by the state Office of Planning and Research. In late 1979, the State Office of Planning and Research (OPR) imposed a series of limitations on the County's ability to approve development permits until such time as the County's General Plan is brought into compliance with State Law.

The County budgeted approximately $\$ 150,000$ to prepare a new General Plan: however, it encountered difficulties in building up its staff capabilities to produce the Plan, so a consultant was retained to carry out the work. With the assistance of the consultant, it seems likely that the new Plan will not be completed until at least next summer, and it may take even longer to adopt the Plan, considering the public hearings that must be held by the Planning Commission and Board of Supervisors. 


\section{Napa County}

The Napa County General Plan is an amalgamation of General Plan elements that have been prepared and adopted at various points in time. The basic Land Use Element adopted in December, 1975, is entirely silent on the subject of geothermal development. However, the combined Conservation and Open Space Element, adopted by the Board of Supervisors in June, 1973, in a section titled "Managed Production of Resources" mentions geothermal in three policy statements.

The first policy statement in which geothermal development is mentioned states:

\footnotetext{
"Prepare priority list identifying critical areas and features threatened by destruction and encourage their inclusion in a natural resource conservation and/or open space easement area [in] which...mining, excavation, drilling or otherwise exploring for minerals, geothermal, sand, gravel, or hydrocarbon resources should be prohibited." (pp.8-9)
}

The second policy statement in which geothermal resources are mentioned states:

\footnotetext{
"Re-examine land use policies in light of the steadily expanding body of knowledge and findings forthcoming from several current and proposed federal, state, regional, and local monitoring feasibility and planning programs. The Legislature's enactment of the Porter-Cologne Act has vested within the State Water Resources Control Board's specific authority to promulgate specific policies regarding many aspects of water quality in categories such as ... thermal waste waters." (p. 15)
} 
The third, and perhaps the most important, policy statement regarding geothermal development is contained on page 16 and states:

\footnotetext{
"Establish policy on geothermal energy exploration and development (mostly in the Calistoga Area) considering the potential adverse environmental effects such as noise pollution, air pollution, water pollution, and poorly located transmission lines that can accompany improper geothermal development."
}

\section{Mendocino County}

Mendocino County's General Plan is a compilation of Plan elements prepared between 1955 and 1974 and adopted by the Board of Supervisors at. various times between 1967 and 1977. In November of 1978, the adequacy of this Plan was challenged in a lawsuit brought against the County. The case was heard in the local Superior Court; and in December of 1978, a preliminary injunction was issued which severely restricted the County's ability to issue zoning and subdivision permits until such time as an adequate General Plan was developed. At that time, the County undertook to prepare a new General Plan that would satisfy the legal requirements for adequacy. Subsequently, in January of 1980, a Draft General Plan/EIR was prepared. This Draft Plan has now been disseminated for public review, and hearings before the Planning Comnission are under way.

Since it is this new Plan that will affect future geothermal development in the County, we: have limited our analysis to it rather than reviewing the old General Plan elements. 
The chapter of the Plan dealing with energy contains a short discussion of the geothermal resources in the County. This section notes that geothermal exploration is going on in the southeast corner of Mendocino County and that no commercial development has yet occurred. This section goes on to indicate that PG\&E has plans to expand their operations into Mendocino County some time between 1985 and 1990, and also notes that there are various environmental problems associated with geothermal development of which the most significant is air pollution.

Among the energy issues identified in this chapter is one relating to geothermal energy: "Impacts of exploration and production of geothermal energy and its potential contribution to long-term energy needs." (p. 44) Moreover, at the end of the chapter, two of the numerous policies dealing with energy being suggested for adoption by the County deal with the questions of geothermal development. The first policy states, "Encourage and promote the research and development of the direct heat applications of geothermal energy," and the second states, "The development of the County's geothermal resources should further the County goal to be energy self-sufficient." (p. 48)

The land use maps that accompany the Plan, one containing the land use recommendations being proposed by the County's Planning Department, and the other containing the proposals of the citizen's advisory committees, are in agreement that the lands within the KGRA should be designated as Range Lands, 200 Acres. A third map titled "Biological 
Resources" Indicates that Pieta Creek and Tyler Creek are important streams for steelhead and rainbow trout; and, furthermore, that there is a significant natural area associated with a portion of these creeks at the westerly edge of the KGRA. 
B. THE GENERAL PLANS' INDIRECT RELATIONSHIP TO GEOTHERMAL DEVELOPMENT

In addition to the specific statements that each Plan has to make about geothermal development, there are inevitably a number of other policies contained within the Plan that can affect or will be affected by geothermal development. Most of these policies which have an indirect effect on geothermal development can be found within the conservation elements of the General Plans. By and large, these policies deal with broader environmental issues such as soil erosion, stream siltation, and air quality. Quite a number also deal with questions of wildlife preservation, scenic qualities, preservation of plant species, and compatability with adjacent land uses.

Some policies of this nature have the effect of outright exclusion of geothermal development from certain areas. Examples of this type of policy would be policies adopted by Napa and Sonotia counties to preserve the integrity of prime agricultural areas. The larger number of policies, however, do not exclude geothermal development, but rather impose restrictions on the way in which development will be allowed to occur. An example of this type of policy might be the proposal in Mendocino County's Draft General Plan that, "The County shall protect ground and surface waters from contamination by industrial wastes, particularly toxic substances." (p. 112) In a number of cases, the development of geothermal energy can actually facilitate achievement of goals or policies expressed in local General Plans. For example, 
in Mendocino County's Draft General Plan, there is a proposed goal that, "Mendocino County shall utilize all local sources of energy with emphasis on those sources which are renewable and/or non-polluting (solar, windpower, wood, geothermal, waste recycling, etc.)." (p. 50) 
C. GENERAL ATTITUDE TOWARD GEOTHERMAL DEVELOPMENT AND POTENTIAL CONFLICTS

As we have seen from the above analysis, each county has handled the question of geothermal development in their General Plan in an individual manner. While there is at least some mention of geothermal in all of the Plans (keeping in mind that Lake County has yet to prepare their new General Plan), in no one Plan can there be said to be extensive coverage of the topic. And, clearly, none of the four counties in the KGRA have an adopted Geothermal Element. Sonoma County's General Plan, when taken together with the Franz Valley Specific Plan (described subsequently in this report), contains the most thorough consideration of the subject.

Considering the multitude of topics that a County General Plan must by law include, and the range of issues that each County regards as highly important, it is not altogether surprising that the Plans we have evaluated do not concentrate on geothermal development more fully. This is particularly true in the cases of Napa and Mendocino counties, where the level of activity with regard to the geothermal resource is still very low. It is also understandable, in light of the relative recency of the increasing pressures to develop the resource as an alternative energy source, and in light of the emerging state of our understanding of the environmental consequences of large-scale geothermal development.

In spite of these factors, each county that has a viable Plan in existence, or at least available for consideration, has at tempted to establish policies that express its overall attitude toward 
geothermal development. Moreover, each Plan contains a number of policies which by inference establish the control parameters for geothermal development. In general, the three counties whose Plans we have evaluated express a cautious attitude about geothermal development. This attitude probably reflects a basic understanding of our society's need for new energy sources and a desire to receive tax and royalty revenues from development, tempered by an awareness of the potential undesirable environmental effects of large-scale development. The statement contained on page 17 of Sonoma County's General Plan exemplifies the prevailing attitude:

\footnotetext{
"It shall be the goal of Sonoma County to provide for a planned production within geothermal-resource areas. A program of planned geothermal production should focus on maximum long-term utilization of the resources and on the mitigation of adverse environmental impacts."
}

It is not, of course, possible to predict what the future Lake County General Plan will say about geothermal development. They do appear at the present to be considering the inclusion of a Geothermal Element in the Plan; and the pressures for geothermal development and the fact that the KGRA covers a substantial . proportion of the land area of the County would seem to militate for more than cursory treatment of the subject. Unfortunately, no conclusion regarding the future General Plan's position on geothermal development can be drawn from the goals and policies that were suggested last year for inclusion in the Plan by a Citizen's Advisory Committee appointed by the Board of Supervisors for that purpose. The "Policy Recommendations from the General Plan Advisory Committee" statement to the Board of Supervisors submitted on April 23, 1979, is entirely silent on the subject 
of geothermal development. However, a policy statement was adopted by the Board of Supervisors last July 9 th that is generally consistent with policies adopted by the other counties in their General Plans. The Lake County policy says in part, "Lake County has a potentially valuable geothermal resource that should be developed in an environmentally sound manner which is consistent with the predominant values of the local citizens."

Each of the four KGRA counties seems prepared to accept geothermal development within their boundaries provided adverse environmental/social/economic impacts are adequately mitigated. It is primarily in the area of environmental impacts that the encouragement of development in a Geothermal. Element is most likely to conflict with established General Plan policies. The Plan elements that are most likely to contain potentially conflicting policies include Land Use, Conservation, Open Space, Seismic, Noise and Scenic Highways. Presumably, however, considering the attitudes of the counties, as well as the State's requirements for internal consistency within a General Plan, any policies adopted as part of a Geothermal Element would include consideration of the types of environmental impacts (such as air quality, sedimentation, soil erosion and wildlife habitat preservation) addressed by these other Plan elements. If this, in fact, proves to be the case, then there would be no conflict between the Geothermal Element and the other Plan elements; any conflict that resulted would be between actual development and the effectiveness with which existing policies were enforced. 


\section{GEOTHERMAL ELEMENTS}

\section{State Law}

One of the most recent additions to State planning law (January 1,1979 ) is the provision for a Geothermal Element in County General Plans. Among the changes that $A B 2644$ made in the laws relating to the process of approving geothermal development was an addition to Section 25133 of the Public Resources Code defining a Geothermal Element as,

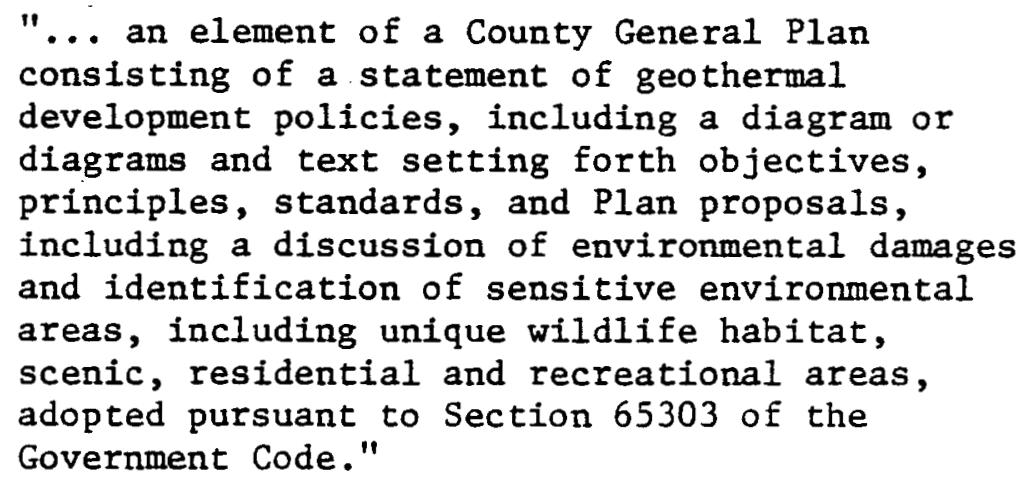

In an effort at rationalizing the process for approving geothermal development, $A B 2644$ provided that the State Division of $0 i 1$ and Gas may delegate its lead agency responsibility under CEQA for all geothermal exploratory projects, "... to a county which has adopted a Geothermal Element, as defined in Section 25133, for its General Plan." (Public Resources Code, Section 3715.5). Moreover, AB 2644 further provided that the California Energy Commission (CEC), 
"... may, at the petition of a county which has adopted a geothermal element for its general plan, approve an equivalent certification program which delegates to that county full authority for the certification of all geothermal power plants within such county." (Public Resources Code, Section 25540.5.)

During the time since $A B 2644$ became effective, there has not been a noticeable rush by counties with geothermal resources within their boundaries to prepare and adopt Geothermal Elements. In fact, the only California county with an adopted Geothermal Element is Imperial County; and Imperial County adopted their element in November, 1977, before the passage of $A B$ 2644. While Imperial County has assumed lead agency status over exploratory projects, due at least in part to the additional requirements imposed by CEC regarding the format of hearings, they have not subsequently petitioned the State for lead agency status over power plants. There may also be little incentive for them to assume CEC's power plant siting authority since they already have authority in this regard for power plants under $50 \mathrm{MW}$ in size, and virtually all the power plants proposed to date have been within this limit.

As they are authorized to do, in the case of all General Plan elements, the Office of Planning and Research (OPR) has recently prepared a set of draft Geothermal Element guidelines that describe the contents of county Geothermal Elements. These draft guidelines are now being reviewed by interested agencies and individuals, and OPR will accept comments and consider possible revisions prior to adoption 
of the final guidelines. Essentially, these draft guidelines (see ATTACHMENT A) suggest that a county's Geothermal

Element should identify the nature of the resources, the process of development, and the environmental, social and economic effects of development; establish policies to minimize adverse effects and to deal with questions of power plant siting, direct heat applications, transmission line corridors, and monitoring; and specify measures for implementing the element.

2. Counties' Positions Regarding Preparation of Geothermal Elements

As mentioned previously, none of the four KGRA counties has adopted a Geothermal Element to their General Plan. This is probabily true for a number of reasons, including some discussed above, i.e. the competing demands of higher priority issues, the relative recency of development pressures, a rather ambivalent attitude about facilitating development in light of potential adverse environmental effects, etc. The recent preparation of Geothermal Element Guidelines by the State, and the passage of $\mathrm{AB} 2644$ would appear to have done little to stimulate the enthusiasm of the counties in this regard.

Lake County is, nevertheless, perhaps the farthest along in its interest in preparing a Geothermal Element. As part of the Request for Proposal that was sent out to prospective General Plan consultants, a section of the Work Program included the need for a Geothermal Element. Consideration 
is being given to incorporating this as part of an Energy Element.

The Napa County Conservation, Development and Planning Department apparently considered the idea of preparing a Geothermal Element, but felt instead that the preparation of an Energy Element would be preferable. This idea was then discussed with the Board of Supervisors at a meeting several months ago. While the idea was not rejected by the Board, there appeared to be little immediate enthusiasm for the project, and so it was dropped for the time being.

In Mendocino County, the new Draft General Plan contains a chapter on energy that might be considered a rudimentary Energy Element. A relatively small part of this section of the Plan deals with geothermal development. This is to be expected in light of the minor part of the County covered by the KGRA, the fact that the existence of a commercial resource has yet to be fully demonstrated, and the other energy sources, such as offshore oil and gas, solar and wind, that are also of interest to the County. Nevertheless, the county has an undoubted interest in energy as evidenced by their proposed long-term goals, "The county shall seek to be energy self-sufficient by the year 2000" (page 47), and the County Planning Director has expressed substantial interest in preparing a full Energy Element.

The Sonoma County Planning Department has taken a different approach to the question of preparing a Geothermal Element. The Conservation Element of their General Plan contains the recommendation that, "A comprehensive geothermal-resource 
management program should be formulated and utilized" (p. 73). In the eyes of the Planning Department staff, this management program is administratively composed of the geothermally-related policies contained in the General Plan, the policies and proposals of the Franz Valley Specific Plan, the standards and conditions currently being written into a proposed Geothermal Resource Zoning District, and a yet-tobe prepared Master EIR covering the areas within the Geothermal Resource Zoning. District. In this way the County feels it is preparing itself, in a planning sense, to deal with the problems of geothermal development, and has no immediate interest in preparing a Geothermal Element per se.

\section{Imperial County's Geothermal Element}

The Geothermal Element prepared for Imperial County is the first, and thus far the only, Geothermal Element that has been adopted in California. As such, it is appropriate to review and analyze the work that was done there for possible application by the four counties in the Geysers-Calistoga KGRA.

There are, of course, substantial differences between geothermal development in the Imperial Valley and geothermal development at the Geysers. The resource itself is quite different; the Imperial Valley has a hot water resource, while the Geysers, at least to date, is primarily dry steam. Topographically, the two development areas are at opposite extremes with the inordinately level surfaces encountered in the Imperial Valley and the very steep and rugged terrain prevailing in the Geysers. Taken together, these differences of resource type and topography impose unique types of problems that must 
be addressed in the course of planning for development. Therefore, much of the technical analysis that underlies the Imperial County Geothermal Element is of little value in the Geysers. Nevertheless, in spite of the differences in situation between the two areas, there may be some useful lessons to be learned from the approach taken by Imperial County in their pioneering effort.

Imperial County initially looked at the development of their geothermal resource from a cautiously optimistic viewpoint a few years ago. The County General Plan's Conservation Element contained the following objective: "Provide for the maximum feasible development of geothermal energy, water, and minerals while assuring the maintenance of environmental quality." A separate document titled "Imperial County Goals" published in February, 1975, contained goals similar to the General Plan (see ATTACHMENT B), and the General Plan itself went on to state a number of policies (see ATTACHMENT $C$ ) which are consistent with the overall objective.

From this policy base, and after a decision had been made to commence work on the Geothermal Element, the County prepared a draft outline of the element and developed a series of issues, goals and objectives to guide the research work being done for the element's data base. This research focussed on four broad subjects: resource assessment; geographical and environmental analysis; economics and political/legal issues.

The work done on resource assessment, "... was designed to determine the size, magnitude, production potential, and physical 
characteristics of the geothermal resource ..." and, "The interrelationships between subsidence, seismicity and heat withdrawal were also studied." (p. 31) "The geographical and environmental analysis focused on the effect of removing land from agricultural production and determining the environmental impact of development." (p. 34) In addition, as part of this work, a public opinion survey was undertaken to ascertain residents' attitudes toward geothermal development.

The economics research evaluated "... the costs of geothermal development, its economic impact, and analyzed the reaction of various sections of the county's economy to geothermal development. Tax aspects ... were also discussed." (p. 41) And, finally, "The Political/Legal analysis addressed the need for regulating the political environment of the county's energy development, legal and jurisdictional aspects of geothermal development, and potential policies." (p. 44)

As a result of the research conducted in this phase of the planning process, a series of specific issues were raised that appeared to call for a policy response on the part of the County. The issues that were raised included:

"1. Optimum use of the resource;

2. Subsidence;

3. Seismic activity;

4. Preservation of agricultural lands;

5. Transmission lines;

6. Use and conservation of water;

7. Non-electric uses of energy; 
8. Economic, social and fiscal impacts;

9. Environmental Impact Reports;

10. Application of County regulations;

11. Zoning administration;

12. Flow of information to the public." (p. 57)

For each of these issues the County then developed an appropriate policy response. For example, on the issue of seismic activity, the following policy was adopted: "In order to determine any effects of geothermal development on seismic activity, the County shall require producers to participate in any seismic monitoring network which may be established for the purpose of providing background data on seismic occurrence." (p. 59)

The element concludes by discussing implementation. Specific implementation measures are assigned to the Planning Department, the Public Works Department, the Personnel Department and other County departments. In addition, the implementation measures are divided into time frames: "short range policies which are to be initiated immediately and concluded within one year; medium range policies which shall be completed within a five-year period; and long-term policies which are either of a continuous nature or, for various reasons, cannot be immediately initiated." (p. 67) An example of a short range implementation measure for which the Planning Department is responsible is to, "Initiate procedures to amend the County's zoning ordinance to comply with the policies outlined in Issue 11." (p. 67) An example of one of the Public Works Department's medium and long range implementation responsibilities 
Is to, "Initiate procedures to coordinate the existing seismic baseline network within Imperial County." (p. 70)

Overall there appears to have been an effort by Imperial County to concentrate the work done on their Geothermal Element as much as possible on the specific issues affecting geothermal development in their county, and to arrive at a set of policies and implementation measures that can be utilized in their day-to-day work. In this way, the practical value of the element as a guide to development decisions has been maximized.

The element's greatest weakness is its omission of direct heat applications; although this was recognized at the outset and one of the implementation measures expressed in the element is to, "Devise plans for the development of nonelectric uses of the geothermal resource." (p. 70) Perhaps as interest in developing direct heat application increases, the county will respond by expanding the content of its Geothermal Element to incorporate provisions for this type of geothermal development.

\section{Analysis}

Considering the quantity of useful information that exists regarding the process and effects of developing the dry steam field area of the Geysers-Calistoga KGRA, technically it would seem to be a relatively simple task to prepare a Geothermal Element for this dry steam resource. On the other hand, considering the widely differing views held by many local residents, particularly in Lake County, the political 
difficulties of agreeing on appropriate policies and implementation measures may be considerable. There is, of course, also the question of the hot water resource. With the focus of attention having been on the use of the dry steam resource for producing electricity, little attention has been paid in the Geysers-Calistoga KGRA to the hot water resource both for the production of electricity as well as for direct heat applications.

Consequently, much less is known about the nature of this resource, its potential for development, and the effects such development would have on each county. The preparation of Geothermal Elements covering this topic would be more difficult and the participants in the process might be equally as tendentious as they are when dealing with dry steam development.

In summary, only one of the four counties has expressed particular interest in preparing a Geothermal. Element per se; although all of the counties have shown some interest in preparing plans and programs that include geothermal development. Three of the counties seem inclined to go farther and prepare an Energy Element or Resource Management Element so as to incorporate other energy and resource-related issues. And Sonoma County is in the process of developing an integrated planning program for geothermal development that includes a General Plan, specific plan, geothermal zoning district and may ultimately include a Master EIR. 


\section{E. SPECIFIC PLANS}

\section{State Law}

Precise plans*, or as they are called "specific plans" under State Law (Government Code, Section 65450.1 et seq), are a technique for preparing very detailed plans as a means of implementing a General Plan. They are often prepared for very small site-specific areas to establish building lines, and they are sometimes prepared as in Sonoma County, for large sections of a county covering many square miles. Moreover, since specific plans are a regulatory tool rather than simply a plan, they can be used in lieu of zoning for an area.

The contents of specific plans, "...shall include all detailed regulations, conditions, programs and proposed legislation which shall be necessary or convenient for the systematic implementation of each element of the General Plan..." (Government Code, Section 65451). The law then goes on to specify that a specific plan include "regulations, conditions, programs and proposed legislation" regarding:

a) The location of and standards for land uses and facilities;

b) The location of and standards for streets, roads, and other transportation facilities;

c) Standards for population density and building intensity and provisions for supporting services;

*Precise plans under California Law (Streets and Highways Code, Sections 740-742) are plans prepared by local governments to protect proposed highway rights-of-way from intrusions by new structures. 
d) Standards for the conservation, development and use of natural resources;

e) Provisions for implementing the open space element; and

f) Other appropriate measures.

Thus, as stated in the Review Draft, General Plan Guidelines prepared by the State Office of Planning and Research, "...the specific plan must contain measures to implement all the policies required in a General Plan that pertain to the area, but it may also include measures to implement policies in optional elements". (p. 71) This latter provision is, of course, germane to geothermal elements.

As expressed above, it appears that the preparation of a specific plan is a major undertaking. In order to ease the financial burden on local governments State law was recently amended (Statutes 1979, Chapter 1207) so that it is now permissible for local governments to prepare specific plans and, "...impose a special fee upon persons seeking governmental approvals which are required to be in conformity with the specific plan. The amount of the fees shall be established so that, in the aggregate they defray, but as estimated do not exceed, the cost of development and adoption of the specific plan." (Government Code, Section 65453(a)). By recovering the costs of specific plan preparation in this way, it is certainly now more feasible for local jurisdictions to consider initiating such a major venture as this. 
Due to the close relationship, mandated by State law, between a specific plan and a General Plan, there is unlikely to be any direct conflict between the two. On the other hand, the specific plan can be expected to provide further refinements of principles initially expressed in the General Plan.

\section{Franz Valley Specific Plan}

At the present time within the KGRA, there is only one Specific Plan, the Franz Valley Specific Plan, prepared by Sonoma County. This Plan covers only a portion of the KGRA in Sonoma County and was adopted by the Board of Supervisors in November, 1979. A section of this Plan deals with geothermal development, and briefly describes the extent of the resource, the development of technology for extracting the resource, and some of the effects of geothermal development on the environment. Two boundaries are established in the Specific Plan that relate to geothermal development.

\footnotetext{
"The secondary geothermal resource permit area includes those portions of the secondard geothermal resource area defined in the General Plan where exploratory drilling is not likely, based on a consensus of the experts in the field, to adversely affect the Peregrine Falcon in the area. Exploratory permits in this area are subject to the California Environmental Quality Act (CEQA) and the maximum feasible mitigation of adverse environmental effects. Permits for production wells for field development and power plant construction should be contingent upon the adequate mitigation of all environmental effects but particularly those on air quality and wildlife.
} 


\footnotetext{
"The secondary geothermal resource study area includes those portions of the secondary geothermal resource within which the impact of geothermal exploration activities on the falcon population cannot be anticipated. Additional studies, including telemetry, are scheduled for the nesting season in 1979 (January to July). The acceptability of geothermal exploration and development within this area will be established upon completion of these studies." (pp. 92-93)
}

The boundary Iines of these two areas, the secondary geothermal resource permit area and the secondary geothermal resource study area, are defined in the Land Use Plan Map. There are two parts to the policy statement contained within the Specific Plan regarding geothermal development. The first part states, "Establish geothermal exploration and production areas where known to be compatible with other resource values and where adverse environmental effects can be mitigated." The second part of the policy statement says, "Mitigate the adverse impacts of geothermal development including transmission lines." (p. 10)

In a section of the Specific Plan dealing with air quality, geothermal again is specifically discussed. Here the nature of the problem is described as follows:

\footnotetext{
"There is a possibility that adverse impacts could be precipitated by geothermal development in the northern part of the study area. Hydrogen sulfide emissions from geothermal installations at the Geysers have reached the region's capacity to dilute the pollutant to acceptable concentrations. Hydrogen sulfide is already a significant odor nuisance to residents in Southern Lake County. Particulate matter emissions are also a source of concern." (p. 44)
} 
Following these discussions, the Plan suggests, "Any geothermal development...should proceed only if adverse air quality impacts can be mitigated as determined through environmental review on the project level." (p. 44)

In another section of the Plan discussing energy, it is pointed out that a $230 \mathrm{KV}$ transmission line has been proposed from the Geysers to Lakeville in southern Sonoma County. The Plan takes the position that, "If approved, adverse impacts would occur to vegetation, wildlife, riparian corridors, fisheries, soils, and noise and visual quality." (p. 63) To deal with this problem, the Plan proposes that, "The County of Sonoma should continue to oppose the proposed Geysers to Lakeville transmission line because it is not consistant with the policies of this Plan." (p. 64)

In addition to the geothermal resource study area and permit area which lies to the north of Knights Valley, the Land Use Plan Map has two other designations within the KGRA: the Knights Valley area is designated for Agriculture and the lands to the north and to the south of Knights Valley are designated for Resource Conservation. The Critical Open-space Map which also accompanies the report contains a number of designations within the area of the KGRA. Included among these designations are Critical Habitat Zone (Peregrine Falcons), Critical Habitat Zone (Federally designated), Pubiic Lands and Parks, Unique Features, Vista Points, Historic Sites, Bicycle Routes, Major Riparian Corridor (200-foot setbacks) and Minor Riparian Corridors (100-foot setbacks). 


\section{Analysis}

Given the resources, the preparation of a specific plan for the dry steam field area could, in theory, be a very useful approach to controlling geothermal development in a manner consistent with established county environmental protection policies. One of the principal benefits of the plan would be the identification of critical resource areas (such as important archaeological sites) in advance of development applications. In this way, areas can be set aside where no disturbance can be tolerated, and other areas can be designated where development will be permitted in a mannèr consistent with identified environmental principles. Thus, a series of resource management proposals would be created that are somewhat analogous to the mitigation measures identified as part of the EIR process. Moreover, the question of how much development to permit can be dealt with, at least in theory, by the establishment of thresholds for various resources such as air, water, land disturbance, etc. In fact, it might be suggested that the preparation of a specific plan achieves many of the same purposes served by an MEA, with the added advantage that the cost is reimbursable. 


\section{F. OVERLAY ZONING}

Overlay zones, or "combining districts" as they are sometimes called, are most often used to denote a single constraining factor, such as a floodplain, that cuts across conventional zoning districts and is not necessarily coterminous with them. In these situations, the requirements defined in the overlay zone are superimposed on the requirements contained in the underlying zoning districts. The effect is to further restrict development. Although overlay zones are not specifically provided for by State Zoning Law (Government Code, Section 65800 et seq), they have, however, been used extensively by local governments to supplement the limitations of established conventional zoning districts. In the Geysers KGRA, there are a number of ways in which overlay zones might be used to control certain aspects of geothermal development. For example, a "critical resource" overlay zone might be created to keep development out of areas such as riparian corridors, floodplains, or habitat management areas. Of course, to the extent that specific plans have been prepared covering these subjects, overlay zones could be redundant.

Another form of zoning that is not strictly overlay zoning, but possesses some of the same attributes, is the special provisions that are usually inserted into zoning ordinances to deal with such matters as off-street parking requirements, landscaping, etc. The approach here is that wherever development occurs involving, for example, off-street parking, then the standards expressed in the ordinance for off-street parking must be complied with: That is, these requirements are not specific to any particular geographic area, but are applied in 
all areas where development takes place. Napa County's Ordinance No. 499, which regulates the use of land for exploration and development for oil, gas or geothermal resources by use permit, is an example of one type of such zoning. Lake County may soon be considering a similar approach when their proposed "Geothermal Resource Development Policy, Conditions and Performance Standards" are brought before the Planning Commission in the future.

This is a particularly effective approach when the subject being controlled occurs over vast areas that are subject to other conventional zoning districts, and where the exact location of the development to be controlled is for some reason uncertain. Obviously, both of these conditions exist in terms of geothermal development in many parts of the KGRA.

Finally, there is the conventional zoning approach that is being pursued by Sonoma County. The Planning Department in this instance is in the process of preparing a Geothermal Resources District, containing a series of standards and conditions that will apply to any new geothermal development located within the areas governed by the District. Because of the extended history of geothermal development in Sonoma County, the geographic boundaries of the resource are better defined than in most other parts of the KGRA, and, consequently, this zoning approach is more feasible. 
SUMMARY AND CONCLUSIONS

With the exception of Lake County, each county has a General Plan or Draft General Plan that addresses geothermal development in a limited way, and that suggests guarded approval of geothermal development, provided it does not result in unacceptable environmental impacts. Moreover, each county has a number of environmental protection policies not solely related to geothermal development that would control the manner in which development will be allowed to proceed. While there would not appear to be any inherent conflict between a Geothermal Element and other General Plan elements considering the prevailing attitudes of the counties, there is also less interest evident on the part of the counties in preparing a Geothermal Element than there is in preparing a more comprehensive Energy Element or an integrated management program.

The experience gained by Imperial County has demonstrated that the preparation of a Geothermal Element can prove of some value to local decision makers involved in the geothermal development process. Considering the amount of research that has gone into the environmental impacts of dry steam production, there is 1ittle doubt that Sonoma, Lake, and possibly Mendocino counties could prepare Geothermal Elements consistent with the new State guidelines covering the dry steam resource with a minimum of technical difficulties. On the other hand, due to the relative lack of interest and investigation into the hot water resource, a Geothermal Element dealing with that subject would be somewhat more difficult to prepare and would likely be expressed in more general terms. In 1ight of the preference that the counties seem to have for preparing an Energy Element or an integrated management program rather than a Geothermal. Element, one possible course of action would be for each county to prepare an 
Energy Element or an integrated management program that would incorporate the Geothermal Element requirements in it. In this way, should a county at some point desire to assume lead agency status over exploratory well and/or power plant permitting, the basic groundwork will have been laid and one of the prerequisites will have been fulfilled.

As far as specific plans and overlay zoning are concerned, there are precedents for using these techniques in the Geysers; and each county has had at least some general exposure to their use. The Franz Valley Specific Plan prepared by Sonoma County contains significant discussion of geothermal development, and demonstrates how this tool can be used to implement the County General Plan. Conceivably, this technique could be useful in implementing the provisions of a Geothermal Element, and might bring a new dimension to this approach to implementation if it were structured in the form of a series of resource management plans. Moreover, the cost reimbursement provisions of State law may make this an attractive approach for the local jurisdictions from a financial point of view.

As we have seen, overlay zoning is most useful in situations where the location of the geothermal resource can be fairly accurately defined, and where the nature of the problems associated with development are generally understood. Under these circumstances, and where geothermal development is the primary land use in an area, the standard zoning classification approach exemplified by Sonoma County's Geothermal Resource District can also prove useful. On the other hand, Napa County Ordinance No. 499 demonstrates the way in which one hybrid form of overlay zoning can be used to control geothermal development where the location of the resource is not known.

Ideally, each county would progress toward an integrated management program comparable to the package that Sonoma County is attempting to develop. This approach recognizes that a Geothermal Element, 
or even an Energy Element, is merely the first step in an overall program that must be established in order to assure the effective development of the resource in a manner compatible with local objectives and sound environmental practices.

The exact mix of general and specific plans and zoning techniques will vary from county to county, depending on local circumstances. Moreover, the approach taken by an individual county toward the control of geothermal development cannot be viewed in isolation from its established planning and regulatory procedures. Nevertheless, as a matter of sound professional practice, any integrated management program governing geothermal development must start from a sound policy and information base.

It should be noted that direct uses of geothermal resources (both hot water and dry steam) are not covered in any of the counties' plans or ordinances. Clearly the focus of attention in the Geysers-Calistoga KGRA has been on electricity production, and this is reflected in the public policy documents. The problem is that direct uses of geothermal energy create different impacts on the counties than the impacts created by electrical production. Therefore, for planning and regulatory purposes, it would be appropriate to treat the two subjects separately.

By not distinguishing between these two forms of geothermal development, unnecessary barriers to direct use projects may be created. For example, the Franz Valley Specific Plan might be interpreted to preclude direct use geothermal development from the Knights Valley area. It is likely that this was the unintentional by-product of a concern that a geothermal power plant could be developed in this beautiful and productive agricultural area. It is not clear that it was the County's intention to preclude all possible direct uses of geothermal resources in Knights Valley. 
A more detailed analysis of the effects of existing county plans and permitting procedures is being undertaken as part of GRIPS' contract extension with DOE to work on small-scale electric and direct heat development.

$\mathrm{DKC} / \mathrm{seb}: \mathrm{dr}$ 
SOURCE: "Review Draft, General Plan Guidelines" OPR, January, 1980.

\section{GEOTHERMAL ELEMENT (GUIDELINES)}

With the dramatic increase in the prices for the traditional forms of energy, the demand for developing geothermal resources has risen sharply, even though this kind of development creates its own environmental and land use problems. Surface measurements indicate only the potential presence of geothermal resources; it takes exploratory wells to verify the find. Further, the power plant must be built where the resources exist, for the steam or water loses heat rapidly when transported. Because most geothermal reservoirs occur in rural, isolated areas, conflicts frequently arise between geothermal development and the preservation of other natural resources.

Through the passage of AB 2644, which became effective January 1 , 1979, the Legislature sought to rationalize the process for approving geothermal development. The law defines three stages in the geothermal development process: exploratory; development field; and the power plant. The law gives the State Division of Oil and Gas, acting as the lead agency under the California Environmental Quality Act, the authority to issue permits for exploratory wells, while it designates counties as the responsible agencies. Counties retain permit authority over development field wells, and the California Energy Commission governs the siting of geothermal power plants. The law also sets deadlines for processing permits in all three stages.

For counties, one of the most important features of the law is the provision providing for a geothermal element in the general plan. If a county has adopted both a geothermal element and adequate procedures for processing geothermal projects, the Division of Oil and Gas may delegate its status as lead agency for exploratory well permits to the county (Public Resources Code Section 25133). In addition, the California Energy Commission may, upon petition of a county, delegate to the county its authority for siting geothermal power plants and related facilities; if the county has adopted a geothermal element and an adequate equivalent certification program (Public Resources Code Section 25540.5).

The law defines a geothermal element as follows:

"Geothermal element" means an "element of a county general plan consisting of a statement of geothermal development policies, including a diagram or diagrams and text 


\section{DEFINITIONS: GEOTHERMAL ELEMENT}

Development Well - "A well drilled for the purpose of producing either high- or low-temperature geothermal fluids in commercial quantities" (Title 14, California State Adminstrative Code Section 1920.1(c)).

Exploratory Geothermal Well - "A well, other than an exploratory well, drilled to discover or evaluate the presence of either lowtemperature or high-temperature geothermal fluids, including steam, where the surface location of the well is at least one-half mile from the surface location of an existing well capable of producing the same type geothermal resources" (Title 14, California Administrative Code Section 1920.1(b)).

Geothermal Field Development Project - "A development project. . . composed of geothermal wells, resource transportation lines, production equipment, roads, and other facilities which are necessary to supply geothermal energy to any particular heat utilization equipment for its productive life, all within an area delineated by the applicant" (Government Code Section 65928.5).

Geothermal Resources - "The natural heat of the earth, the energy in whatever form, below the surface of the earth present in, resulting from, created by, or which may be extracted from, such natural heat, and all minerals in solution or other products obtained from naturally heated fluids, brines, associated gases and steam, in whatever form, found below the surface of the earth, but excluding oil, hydro-carbon gas or other hydro-carbon substances" (Title 14, California Administrative Code Section 1920(e)).

Thermal Power Plant - "Any stationary or floating electrical generating facility using any source of thermal energy, with a generating capacity of 50 megawatts or more, and any facilities appertenant there to. Exploratory, development, and production wells, resource transmission lines, and other related facilities used in connection with a geothermal field development project are not appertenant facilities for the purposes of this division" (Public Resources Code Section 25120).

setting forth objectives, principles, standards, and plan proposals including a discussion of environmental damages and identification of sensitive environmental areas, including unique wildlife habitat, scenic, residential, and recreational areas, adopted pursuant to Section 65303 of the Government Code.

(Public Resources Code Section 25133)

The procedures set up by the Division of Oil and Gas and the California Energy Commission call "for review of submitted geothermal elements by the Office of Planning and Research, using these guidelines on geothermal elements as a standard for judging their adequacy. (Title 14, California Administrative Code Section 
1682.7; Title 20, California Administrative Code Section 1862). Because the requirements for a geothermal element stress environmental considerations and because the adoption of a geothermal element is subject to the California Environmental Quality Act, these guidelines encourage the preparation of a single document that will meet the definition of a geothermal element and, at the same time, satisfy the requirements for environmental documentation under the California Environmental Quality Act.

\section{Content of the Geothermal Element}

Because not all counties have reached the same stage in developing their geothermal resources, variations will inevitably occur in the content of geothermal elements. For counties only contemplating geothermal development, the geothermal element may be rudimentary. For example, it might include a preliminary list of issues associated with geothermal development set aside for further study and establish a general process for reviewing proposals for geothermal development. After some experience with geothermal development, the county can revise the element to reflect what it has learned. On the other hand, a county with existing geothermal development should be able to discuss the issues in depth, presenting a detailed program for processing proposals. As with other issues, the general plan should present data and analysis, policy, and implementation measures for geothermal development.

DATA AND ANALYSIS

Federal and state reports, as well as plans and environmental impact reports prepared for surrounding areas, should be the starting point in describing the environmental setting and the potential for geothermal development. The analysis should include:

- A description of geothermal resources, including:

- The location of reservoirs (known or potential).

- The location of existing and proposed wells.

- An estimate of the ultimate magnitude of geothermal resources.

- A description of each phase in the process of developing the geothermal resource:

- The exploratory phase.

- The development field phase.

- The power plant phase.

- A description of sensitive environmental areas, including:

0 The unique wildlife habitats.

- The scenic areas.

- The recreational areas.

- The residential areas. 
- The areas subject to subsidence and earthquakes.

- The archeaological sites.

- A description of the potential environmental, economic, and social effects of each phase of the geothermal development process, including:

- Potential conflicts with other land uses (e.g., agriculture, forestry, recreation, and residential).

- Water use.

- Water quality.

- Noise and nuisance problems.

- Waste disposal.

- Housing and employment.

- Air quality.

- Subsidence.

- Slope stability.

- Seismic stability.

- Soil erosion.

- A description of geothermal development on state and federal lands within the county.

If any of this information appears in other parts of the existing general plan, the geothermal element may simply refer to the appropriate sections.

The geothermal element should include the following types of policies, plan proposals, and standards, with the specificity dependent largely on the stage of geothermal development in the county:

- Policies, plan proposals, and standards for minimizing conflicts between geothermal development and other land uses, such as agriculture, forestry, recreation, and residential (e.g., identification of areas suitable for development given various constraints).

- Policies and standards for minimizing environmental damage from geothermal development (e.g., environmental performance standards for each of the three phases of development).

- Policies, plan proposals, and standards for siting geothermal power plants.

- Policies for the use of direct heat for space-heating and other industrial processes.

- Policies, plan proposals, and standards for locating power-line transmission corridors.

- Policies and standards for monitoring the environmental effects of geothermal development. 
EXAMPLES OF IMPLEMENTATION MEASURES
The geothermal element should also specify the measures. the county proposes to adopt to carry out its geothermal development policies, such as:

- Adopt geothermal overlay zoning.

- Adopt performance standards governing the environmental effects of geothermal development.

- Establish a program to monitor the effects of geothermal development (e.g., subsidence).

- Amend the county's capital improvement program to include improvements to roads and facilities supporting geothermal development.

- Adopt detailed guidelines for reviewing and approving geothermal projects under the authority delegated to the county by the Division of Oil and Gas and the California Energy Commission. 


\section{ATTACHMENT B}

IMPERIAL COUNTY GEOTHERMAL GOALS - 1975

"To encourage geothermal exploration and development projects in order to increase the store of knowledge surrounding this useful resource. To increase the store of knowledge of geothermal resources, to encourage and promote the beneficial development of geothermal resources for multiple use, including power, water, minerals and other uses, and to assure that the development is compatible with agriculture and our environment."

Source: "Imperial County Goals", February 1975. 


\title{
ATTACHMENT C
}

\author{
GEOTHERMAL GOALS, OBJECTIVES AND POLICIES CONTAINED IN \\ THE IMPERIAL COUNTY GENERAL PLAN
}

\section{EXISTING COUNTY GOALS}

Various Elements of the Imperial County General Plan contain Goals, Objectives and Policies which relate to geothermal development. The pertinent ones are tabulated below:

GOAL

Encourage the exploration for and development of new sources of geothermal energy (Open Space Element).

\section{OBJECTIVE}

Provide for the maximum feasible development of geothermal energy, water, and minerals while assuring the maintenance of environmental quality (Conservation Element).

\section{$\underline{\text { POLICIES }}$}

Encourage development of geothermal energy and water desalinization consistent with environmental protection and the preservation of productive agricultural lands (Open Space Element).

Encourage the exploration and development of geothermal resources by public and private organizations consistent with protection of environmental values (Conservation Element). 
Secure a formal statement of policies and procedures concerning the means of incorporate Imperial County Zoning Restriction in Federal Geothermal Leases (Conservation Element.

Geothermal resources, while potentially of considerable importance, will not be permitted to degrade the natural environment or threaten the continued viability of irrigated agriculture (Conservation Element).

Participate in and promote a program to develop and centralize data relevant to the geothermal resource for the purpose of providing long-range direction based on reliable technical information (Conservation Element).

Source: "Imperial County Goals", February, 1975. 